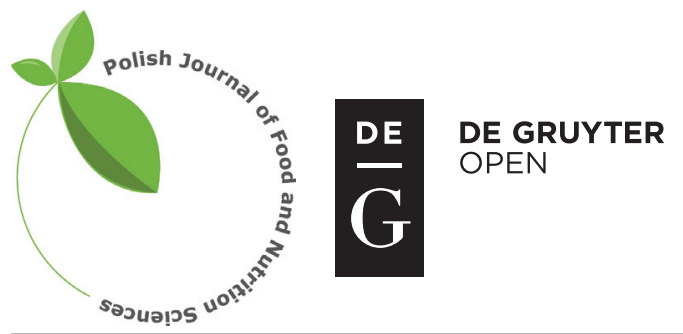

Pol. J. Food Nutr. Sci., 2017, Vol. 67, No. 1, pp. 5-17

DOI: 10.1515/pjfns-2016-0024 http://journal.pan.olsztyn.pl

Review article

Section: Food Technology

\title{
Protein-Lipid Interactions in Different Meat Systems in the Presence of Natural Antioxidants - a Review
}

\author{
Marzanna Hęś \\ Department of Food Service and Catering, Poznań University of Life Sciences, \\ Wojska Polskiego 31, 60-624 Poznañ, Poland
}

Key words: meat, proteins, lipid oxidation products, interactions, plant extracts, nutritional value, essential amino acids

This study presents several aspects of the mutual interaction between lipids and proteins. Nutritional and technological implications of the reaction of oxidized lipids with proteins are discussed. Changes are highlighted in the content of amino acids and protein digestibility, formation of cross-links, flavor compounds, as well as the formation of colored non-enzymatic browning products. Attention is paid to the agents which may determine the reaction of amino acids with the products of lipid oxidation, i.e. the presence of catalysts or inhibitors in the environment, the presence of water, $\mathrm{pH}$ of the environment, temperature or reaction time. It was also noted that the conformation of the protein structure, the surface charge, the affinity, and the accessibility of reactive groups affect the intensity of these interactions.

This review article presents methods which reduce oxidative rancidity due to the use of antioxidant compounds, particularly the possibility of the use of natural antioxidants that reduce the number of lipid and protein oxidation products, and are simultaneously able to model the nutritional value of food.

\section{INTRODUCTION}

Among a number of well-known food components essential for the proper development and functioning of an organism, proteins play an important role. One method to prevent losses and protect the rational use of proteins is to preserve high-protein foods. In most cases, these products also contain lipids or lipid-like substances. During the storage and processing of foods, lipids particularly those rich in polyunsaturated fatty acid residues are oxidized. Oxidation processes are major causes of deteriorating quality. They are responsible for the degradation of aroma, taste, texture and consistency, as well as decreases of nutritive value [Morrissey et al., 1998; Contini et al., 2014]. A deterioration of nutritive value may be a consequence of interactions between lipid oxidation products and protein [Viljanen et al., 2004]. Oxidation products of lipids easily interact with proteins forming lipid-protein complexes leading to the modification of the protein in terms of chemical composition, structure, functionality and digestibility [Xiong, 2000; Soladoye et al., 2015]. Hydroperoxides, carbonylic derivatives and various other lipid oxidation products react with protein modifying their chemical, physical and technological properties. This applies in particular to meat and other animal raw materials, because they act as a source of balanced protein and vitamins,

\footnotetext{
* Corresponding Author: Tel.: +4861 8487331; Fax: +4861 8487430;

E-mail: marzahes@up.poznan.pl (Marzanna Hęś)
}

that is components determining their high nutritional value, which are simultaneously susceptible to oxidation [Hoffmann, 1993; Gray et al., 1996; Santé-Lhoutellier et al., 2008].

The consequences of protein-lipid interactions can be considered in terms of the nutritional and technological value of proteins. The nutritional importance of the interaction of proteins with oxidized lipids generally refers to the reduction of the content or availability of essential amino acids and the reduction of a protein digestibility (loss of enzyme activity, protein cross-linking) [Morzel et al., 2006; Santé-Lhoutellier et al., 2008]. Protein-lipid interactions significantly affect the functional properties of proteins, and thus the quality of the product, which usually deteriorates. The fragmentation of the molecule and the decreased number of polar groups occurring as a result of the oxidation, blocking or crosslinking of amino acids result in a changes in food texture, decrease in protein solubility (due to aggregation or complex formation), and color changes (browning reactions) [Ganhão et al., 2010a; Villaverde et al., 2014].

Oxidative rancidity can be reduced by use of antioxidant compounds that reduce the number of lipid oxidation products, and are simultaneously able to model the nutritional value of food. Due to issues of health safety surrounding food and the growing popularity of food free from synthetic additives, new sources of natural compounds of antioxidant activity have long been sought, and numerous studies confirm the high levels of effectiveness of some plant materials in the reduction of oxidative lipid rancidity. This group includes those plants which have long been used by humans 
due to their positive effect on the organism - e.g. tea, coffee, herbs and spice plants [Shahidi \& Zhong, 2010]. The high content of active compounds in these raw materials enables them to become a source of effective and safe natural food additives and, therefore, it seems particularly important to search for appropriate forms of their application and an assessment of their effectiveness in differently processed meat products [Soladoye et al., 2015]. These additives, due to their long tradition of safe consumption and the content of antioxidative substances, are not only able to reduce the amount of lipid oxidation products, but indeed exhibit this activity in an organism and shape the nutritional value of meat products [Hęś et al., 2007; Hęś \& Gramza-Michałowska, 2016].

Due to the relatively small number of studies in the field of lipid-protein complexes, it is important to determine to what extent the addition of antioxidants may lead to the blocking of the reactive sites of the polypeptide chain, reducing the process of oxidative metabolism and forming lipid oxidation products. Understanding the scale of the mutual interactions between proteins and lipids in the presence of antioxidants is becoming a necessity to improve the quality of processed foods and results from the growth of nutritional and health requirements being applied to processed products.

\section{INTERACTION OF PROTEINS AND AMINO ACIDS WITH LIPID OXIDATION PRODUCTS IN MEAT PRODUCTS}

Proteins are particularly prone to oxidation due to their large contact surface with the environment, their amphiphilic character and the presence of free amino acid residues [Hassan, 2012; Lund et al., 2011]. Park \& Xiong [2007] reported that sensitivity of amino acids in muscle proteins to oxidative modifications depend on the reactive oxygen species origin. Sulfur-containing amino acids were the most sensitive, even to a slight oxidizing condition. Amino acids were also oxidized in the presence of highly concentrated prooxidants. These studies indicate three ways to generate radicals in muscle foods: iron/hydrogen peroxide-, lipoxydase-, and metmyoglobin-catalyzed. Protein reacts readily with both primary and secondary products of lipid oxidation and also non-lipid substances (e.g. polyphenols) which interact with the protein at all stages of oxidation [Veberg et al., 2006; Chelh et al., 2007]. Substances accidentally introduced during processing, e.g. metal ions or mineral impurities [Chelh et al., 2007], the very substances that initiate lipid autoxidation, may also act as oxidants. The kinetics of protein-lipid interaction is determined by the presence of catalysts and inhibitors in the environment, $\mathrm{pH}$ and the presence of water. Protein tertiary structure conformation, surface charge, affinity, and the availability of reactive groups are also of great importance [Hassan, 2012; Lund et al., 2011]. The intensity of these interactions is also affected by the reaction time and temperature. The reactions can be carried out at high speed at room temperature and even in the range of refrigeration and freezing temperatures [Veberg et al., 2006; Hęś et al., 2007; Santé-Lhoutellier et al., 2008]. In the case of preserves, protein oxidation can also initiate the breakdown of hemoglobin and myoglobin [Chelh et al., 2007; Lund et al., 2011].
The range and intensity of protein-lipid interaction in these products increases significantly, even during the addition of $\mathrm{NaCl}$ and thermal denaturation of the protein. Presumably, the first step of complexation is protein denaturation under the influence of oxidized lipids through an attack on active centers in the protein molecule by fatty acid radicals and further formation of complexes.

Among the functional groups of oxidized lipids, the most reactive groups may be listed as: hydroperoxide and peroxide, aldehyde, hydroxyl, carboxyl, epoxy and ketoxy. These groups react with the free functional groups of proteins: amino, amido, thiol, sulfide and disulfide, hydroxyl, $p$-phenol, indole, in peptide bond (Table 1) [Pokorný \& Kołakowska, 2003]. The reaction of hydroperoxides with proteins can be carried out even at room temperature, particularly in the presence of water. Among aldehydes, the highest reactivity is exhibited by aldehydes with lower molecular weights, and their molecular weight dependence against the reactivity towards proteins often exhibits linear correlations. A special reactivity is exhibited by dialdehydes, i.e. malondialdehyde. This reacts with proteins from both functional groups. Ketones formed as a result of autoxidation are less reactive towards proteins, and hydroxyacids bind to proteins during heat treatment and form stable brown condensation products. Ketone alcohols readily form stable simplexes, and epoxides can react with e.g. free carboxyl groups of glutamic and aspartic acid forming the protein [Davídek et al., 1983].

The interaction of lipid oxidation products with proteins runs multidirectionally in terms of both chemical changes, to which protein is subjected, as well as the consequences of these changes. In general, chemical modifications of proteins can cause polymerization of molecules and a decrease in the content of amino acids as a result of oxidation, blocking, functional group transformations and the formation of additional crosslinks [Lund et al., 2011; Zhang et al., 2013]. The directions of these changes are quite conventional, since the oxidation reactions of amino acids may constitute the beginning of protein crosslinking, as well as a transformation of their functional groups. They occur as a result of two basic reactions: oxidation of free amino acid groups in the presence of hydroperoxides and nucleophilic addition in the presence of carbonyl compounds [Davídek et al., 1983]. The ability to initiate protein oxidation is exhibited by the free radicals of fatty acids and their hydroperoxides, which initiate auto-oxidation chain reactions in the product [Aalhus \& Dugan, 2014; Saeed et al., 1999]. They detach hydrogen atoms from the surface of the protein, which leads to the formation of protein radicals. Protein radicals are also reactive; they can interact with fatty acid radicals, other protein radicals or initiate the formation of unoxidized molecule radicals (Figure 1). In reactions with primary products of lipid oxidation, the $\alpha$ carbon in the main chain and the free amino acid residues in the side chain, especially those with free $-\mathrm{NH}_{2},-\mathrm{OH},-\mathrm{SH}$ groups and heterocyclic rings, are most commonly attacked [Pokorný \& Davídek, 1979; Mercier et al., 2004]. The most labile amino acids are, therefore, those which contain a high number of the abovementioned groups, such as lysine, histidine, arginine, proline, tryptophan, tyrosine, cysteine and cystine, and methionine. As a result of these reactions, a series of products are formed, i.e. 
TABLE 1. Functional groups of oxidized lipids and proteins likely to react in lipid-protein interaction. Derived from: Pokorný \& Kołakowska [2003].

\begin{tabular}{|c|c|c|c|}
\hline \multicolumn{4}{|c|}{ Functional groups of oxidized lipids } \\
\hline Hydroperoxide group & $-\mathrm{OOH}$ & Peroxide group & $\stackrel{\mathrm{CH}}{/}=\sum_{\mathrm{CH}}^{\mathrm{CH}}$ \\
\hline Keto group & $=\mathrm{C}=\mathrm{O}$ & & \\
\hline Aldehyde group & $-\mathrm{CHO}$ & Ketol group & $\begin{array}{cc}-\mathrm{CH} & -\mathrm{C}- \\
\mathrm{I} & \mathrm{II} \\
\mathrm{OH} & \mathrm{O}\end{array}$ \\
\hline Epoxy group & $-\underbrace{\mathrm{CH}}_{\mathrm{O}^{\prime}}-\mathrm{CH}-$ & Hydroxy group & $=\mathrm{CHOH}$ \\
\hline Dihydrofuran group & $\underset{-\mathrm{CH}}{\mathrm{CH}}=\underset{\mathrm{CH}}{\mathrm{CH}}$ & Carboxyl group & $-\mathrm{COOH}$ \\
\hline \multicolumn{4}{|c|}{ Functional groups of proteins } \\
\hline Amine group & $-\mathrm{NH}_{2}$ & & $-c$ \\
\hline Amide group & $-\mathrm{CONH}_{2}$ & $p$-Phenol group & \\
\hline Thiol group & $-\mathrm{CH}_{2} \mathrm{SH}$ & & \\
\hline Sulfide group & $-\mathrm{CH}_{2}-\mathrm{S}-\mathrm{CH}_{3}$ & & $\mathrm{OH}$ \\
\hline Disulfide group & $-\mathrm{CH}_{2}-\mathrm{S}-\mathrm{S}-\mathrm{CH}_{2}$ & & \\
\hline Peptide bound & $-\mathrm{CO}-\mathrm{NH}-\mathrm{CH}_{2}$ & Indole group & \\
\hline Hydroxyl group & $-\mathrm{CH}_{2} \mathrm{OH}$ & & $\mathrm{N}$ \\
\hline
\end{tabular}

cysteic acid from cysteine, and kynurenine and N-formylkynurenine from tryptophan, and sulfoxide and sulfone from methionine [Zhang et al., 2013; Xiong, 2000; Xiong et al.,

\begin{tabular}{|c|c|c|c|}
\hline $\mathrm{L}+\mathrm{R}^{\cdot}$ & $\stackrel{\mathrm{O}_{2}}{\rightarrow}$ & $\mathrm{L}^{\bullet}+\mathrm{LOO}^{\bullet}+\mathrm{LOOH}+\mathrm{R}$ & \multirow{3}{*}{$\begin{array}{l}\text { Generation } \\
\text { of lipid radicals }\end{array}$} \\
\hline $\mathrm{LOOH}+\mathrm{Fe}^{2+}$ & $\rightarrow$ & $\mathrm{LO}^{\bullet}+\mathrm{OH}^{-}+\mathrm{Fe}^{3+}$ & \\
\hline $\mathrm{LOOH}+\mathrm{Fe}^{3+}$ & $\rightarrow$ & $\mathrm{LOO}^{\cdot}+\mathrm{H}^{+}+\mathrm{Fe}^{2+}$ & \\
\hline $\mathrm{P}+\mathrm{L}^{\circ}$ & $\rightarrow$ & $\mathrm{P}^{*}+\mathrm{L}$ & \multirow{6}{*}{$\begin{array}{l}\text { Generation of protein } \\
\text { radicals }\end{array}$} \\
\hline $\mathrm{P}+\mathrm{LO}^{\circ}$ & $\rightarrow$ & LOPP & \\
\hline $\mathrm{P}+\mathrm{LO}^{\circ}$ & $\rightarrow$ & $\mathrm{P}^{\bullet}+\mathrm{LOH}$ & \\
\hline $\mathrm{P}+\mathrm{LOO}^{\circ}$ & $\rightarrow$ & LOOP & \\
\hline $\mathrm{P}+\mathrm{LOO}^{*}$ & $\rightarrow$ & $\mathrm{P}^{*}+\mathrm{LOOH}$ & \\
\hline $\mathrm{P}+\mathrm{LOOH}$ & $\rightarrow$ & $\mathrm{LO}^{\bullet}+\mathrm{P}^{\bullet}+{ }^{\bullet} \mathrm{OH}+\mathrm{H}^{\bullet}$ & \\
\hline $\mathrm{LOO}^{*}+\mathrm{P}$ & $\rightarrow$ & LOOP & \multirow{8}{*}{ Protein binding } \\
\hline $\mathrm{LOOP}+\mathrm{O}_{2}$ & $\rightarrow$ & 'OOLOOP & \\
\hline$\cdot$ OOLOOP $+\mathrm{P}$ & $\rightarrow$ & PO॰OLOOP & \\
\hline $\mathrm{P}^{\cdot}+\mathrm{P}$ & $\rightarrow$ & $\mathrm{PP}^{\bullet}$ & \\
\hline $\mathrm{P}^{\bullet}+\mathrm{P}^{\cdot}$ & $\rightarrow$ & PP & \\
\hline $\mathrm{P}^{*}+\mathrm{L}^{\cdot}$ & $\rightarrow$ & PL & \\
\hline $\mathrm{P}^{*}+\mathrm{LO}^{*}$ & $\rightarrow$ & POL & \\
\hline $\mathrm{P}^{*}+\mathrm{LOO}^{*}$ & $\rightarrow$ & POOL & \\
\hline
\end{tabular}

FIGURE 1. The effect of lipid radicals on cross-linking of proteins; L - lipid, P - protein, R - radical. Derived from: Sikorski [2002].
2010; Lund et al., 2011]. The sensitivity of methionine to oxidation is dependent on its location in the protein - greater resistance is exhibited by methionine grouped in hydrophobic form as compared to the free residues on the protein surface [Viljanen, 2005]. Hydroperoxides can react with the primary amine group of lysine and consequently the imino groups are formed, and then the lysine residues are converted into Schiff bases in the further reactions. Similar transformations are observed for lysine residues in reactions with secondary aldehyde products of lipid oxidation [Estévez, 2011; Zhang et al., 2013]. These modifications occur with the formation of both covalent (Figure 2) and electrostatic bonds. There is also a possibility of the non-covalent binding of a number of hydrogen bonds. The number of the possible combinations of these interactions is very large. Secondary reactions occur mainly between aldehydes and the free $-\mathrm{SH}$ and $-\mathrm{NH}_{2}$ groups

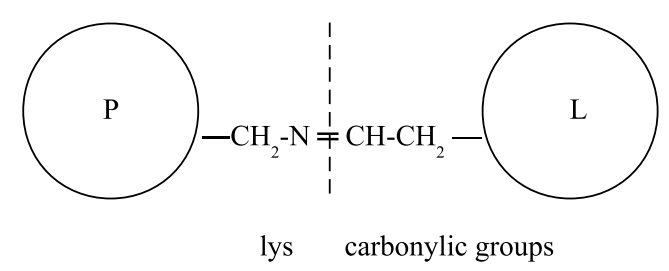

FIGURE 2. Example of the protein-lipid covalent bond; L - lipid phase, $\mathrm{P}$ - protein. Derived from: Pokorný \& Kołakowska [2003]. 
in the side chains of the protein and result in blocking of amino acid residues. The most susceptible are cysteine and lysine. Even a small amount of aldehydes can bind $\varepsilon$-amino groups of lysine, which results in the formation of colorless pyrrole compounds with Schiff base properties [Veberg et al., 2006; Chelh et al., 2007]. Imines formed in the reactions of aldehydes with lysine residues can be, as a result of the cyclization reaction, converted into pyrimidine rings, which results in an increase in the hydrophobicity of the protein and an increase its susceptibility to crosslinking. Moreover, these bonds are formed with the contribution of other nucleophilic amino acid residues, e.g. sulfhydryl group of cysteine or imidazole group of histidine. As a result of the aldol condensation and pyrrole polymerization, brown-colored macromolecular compounds are formed. The formation of colored compounds is dependent on the presence of aldehydes and the availability of free amino groups in the side chains of the protein, and the color intensity is further increased with an increase in the unsaturation degree in the lipid fraction. Chemically, these products are complexes of Schiff bases and Michael adducts and exhibit properties similar to melanoids formed in the classic Maillard reaction [Adams et al., 2009; Estévez, 2011]. At the same time, the formation of chromophores with different structures may occur, that is molecules capable of fluorescence emission, which may also have a brown color [Veberg et al., 2006; Chelh et al., 2007]. Chromophores are relatively stable and their fluorescence intensity depends on the interaction intensity of compounds involved in the reaction - highly fluorescent complexes form $\varepsilon$-amino groups of lysine as well as dityrosine with aldehydes [Chelh et al., 2007].

The selection of proper $\mathrm{pH}$ of the environment constitutes the basis for the limitation of nucleophilic addition reaction. Different $\mathrm{pH}$ conditions had an effect on amino acids losses. There is lack of data in the available literature on the reactivity of amino acids depending on the ion structure (zwitterion form and cation form). The addition encompasses a nucleophilic attack by the basic nitrogen compound $\left(\mathrm{H}_{2} \mathrm{~N}-\mathrm{G}\right)$ on the atom of carbon of the carbonyl group. Protonation of $\mathrm{H}_{2} \mathrm{~N}-\mathrm{G}$ leads to the formation of ${ }^{+} \mathrm{H}_{3} \mathrm{~N}-\mathrm{G}$ ion, which does not contain a free electron pair, and therefore is no longer a nucleophile. Therefore, higher acidity of the environment should not favor addition. However, a subject of protonation can also be the carbonyl group. Protonation of oxygen atom of this group makes the carbon atom more susceptible to the nucleophilic attack and thus, if we consider a carbonyl compound, higher acidity of the environment will favor the addition reaction. Therefore the conditions under which addition occurs the most slowly are the result of a compromise: the solution cannot be too acidic, to not provide too high an amount of protonic carbonyl compound, but it also cannot be too low in acidity for the free nitrogen compound concentration to be lowered [Morrison \& Boyd, 1990].

The results of previous studies show that an important role in the environment of the reaction between proteins and lipids is played by the presence of transition metals [Gatellier et al., 2009]. Copper and iron ions interact with proline, arginine and tryptophan residues. $\mathrm{Cu}^{2+}$ cations have the ability to lower activation energy in the initiation stage of fatty acid oxidation through the direct transfer of free radi- cals on the tryptophan residues. A tryptophan radical (Trp*) is formed and may react with oxygen, resulting in a tryptophan - oxygen $\left({ }^{\bullet} \operatorname{TrpO}, \operatorname{TrpOO}{ }^{*}\right)$ radical. Tryptophan - peroxide radicals react with fatty acid molecules causing their oxidation and the production of tryptophan hydroperoxides, which decompose rapidly to kynurenine and N-formylkynurenine [Chowdhury et al., 1995]. Additionally, the indole ring of tryptophan is very sensitive to oxidative interactions and may be irreversibly converted to different products, among others oxindolealanine, which is decomposed to $\mathrm{N}$-formylkynurenine. Conjugated tryptophan is more susceptible to oxidation than its non-conjugated form. During testing of model systems containing the addition of vitamin $\mathrm{C}$ and $\mathrm{Fe}^{2+}$ ions, it has been found that residues undergo oxidation more rapidly at the $\mathrm{N}$-terminus of tryptophan than at the $\mathrm{C}$-terminus. The degree of tryptophan oxidation is also dependent on the presence of other amino acid residues in the environment. The oxidation of these amino acid residues by the attachment of $\mathrm{Cu}^{2+}$ ions constitutes the first step in the oxidation of proteins and occurs until the propagation stage of the reaction is started [Gatellier et al., 2009]. The formation of additional bonds within the proteins as well as protein and lipid bonds leads to protein crosslinking, which results in a change in the conformation, chemical and technological properties of the protein. Most susceptible to the formation of these bonds are sulfur amino acids, serine, arginine, lysine, threonine and tyrosine, and these reactions occur most intensively in the presence of aldehydes, epoxides and peroxides (Table 2) [Pokorný \& Davídek, 1979; Mercier et al., 2004]. In the case of sulfhydryl groups, the formation of disulfide bridges (-SS-) is observed, and, from the two oxidized tyrosine residues, the formation of dityrosine is observed. Malonic aldehyde crosslinks $\varepsilon$-amino groups of lysine and the N-terminal end of aspartic acid residues. Another reactive compound formed as a secondary product of lipid autoxidation - glyoxal - similar to its homologs, forms in turn crosslinks with guanidyl groups of arginine residues [Viljanen, 2005]. Transfer of radicals by amino acid residues is another reaction, after oxidation, blocking and forming crosslinks, leading to a reduction of amino acid content in the protein. At the first stage, a hydrogen atom

TABLE 2. Functional groups of protein reacting with autoxidized lipids with formation of covalent bonds. Derived from: Pokorný \& Davídek [1979].

\begin{tabular}{|c|c|c|}
\hline $\begin{array}{l}\text { Functional group } \\
\text { of protein }\end{array}$ & $\begin{array}{c}\text { Amino } \\
\text { acid }\end{array}$ & $\begin{array}{l}\text { Reacting products } \\
\text { of lipid oxidation }\end{array}$ \\
\hline Tiol & Cysteine & $\begin{array}{l}\text { Hydroperoxides } \\
\text { Aldehydes }\end{array}$ \\
\hline Disulphide & Cystine & Hydroperoxides \\
\hline Tioether & Methionine & Hydroperoxides \\
\hline Amine & Lysine & $\begin{array}{l}\text { Hydroperoxides } \\
\text { Aldehydes }\end{array}$ \\
\hline Hydroxyl & Serine, Threonine & Epoxides \\
\hline Carboxyl & $\begin{array}{l}\text { Glutaminic acid, } \\
\text { Aspartic acid }\end{array}$ & $\begin{array}{l}\text { Hydroperoxides } \\
\text { Epoxides }\end{array}$ \\
\hline Phenols & Tyrosine & Aldehydes \\
\hline
\end{tabular}


is detached from the protein molecule $(\mathrm{PH})$ by a non-protein radical $\left(\mathrm{A}^{\bullet}\right)$, and transfers a protein molecule to a protein radical $\left(\mathrm{P}^{\bullet}\right)$. In the next stage, the protein radical is detaching hydrogen from the other occurring compounds forming non-radical protein or protein hydroperoxides depending on participating compound (Figure 3).

The importance of the changes resulting from the interaction of proteins with primary and secondary lipid oxidation products depends on the system in which these reactions occur. In meat products, interaction of proteins with hydroperoxides as well as with secondary oxidation products are of great importance, because they lead to a reduction in the nutritional value of meat proteins [Hęś et al., 2007, 2012]. The total lipid content has a significant impact on the oxidative damage to proteins occurring during frozen storage and subsequent processing of beef patties. Patties with higher fat content underwent the more intense protein oxidation as assessed by formation of protein carbonyls and Schiff bases structures, highlighting the timely interaction between proteins and oxidizing lipids [Utrera et al., 2014a]. Lipid and protein oxidation seemed not to be governed by similar mechanisms, lipid content and lipid source however had a significant influence on both components oxidation in experimental fermented sausages. Fatty acid composition of the samples and the presence of antioxidants showed a significant influence on the lipids oxidative stability, which was not found in the case of proteins. Considering the essential consequence of lipid and protein oxidation, the quantity and quality of the fat added to meat products should be considered to improve its sensory quality and nutritional value [Fuentes et al., 2014]. In model systems, such as muscle protein specimens or protein-stabilized emulsions, more attention is paid only to the presence of carbonyl derivatives, which arises from the interaction of proteins with secondary products of fatty acid oxidation. This results

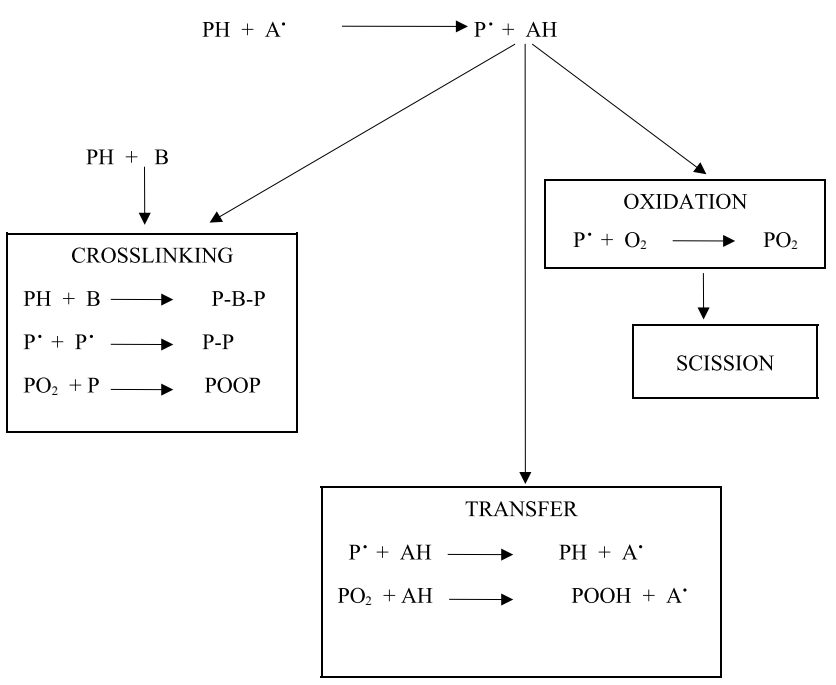

$\mathrm{PH}-$ Protein

$\mathrm{A}^{*}$ - Non-protein radical (here: lipid radical)

B - Breakdown products

$\mathrm{P}^{*}$ - Protein radical

FIGURE 3. Schematic representation of reactions of proteins with oxidized lipids. Derived from: Karel et al. [1975]. from the fact that they are easily measurable, allow an estimation of the range of protein-lipid interactions, and their presence is a consequence of the reaction of proteins with primary lipid oxidation products [Veberg et al., 2006; Chelh et al., 2007].

\section{THE CONSEQUENCES OF PROTEIN-LIPID INTERACTIONS}

\section{The nutritional value of proteins}

The nutritional importance of protein interactions with oxidized lipids is generally limited to two phenomena: the reduction of the content or availability of exogenous amino acids and the reduction of protein susceptibility to proteolytic enzyme activity [Chelh et al., 2007; Santé-Lhoutellier et al., 2008; Gatellier et al., 2009; Lund et al., 2011]. The availability of amino acids decreases as a result of their oxidation, blocking or the formation of additional crosslinks [Lund et al., 2011]. The decrease in amino acid content as a consequence of oxidation reactions refers to cysteine, lysine, methionine and tryptophan, while lysine and cysteine undergo blocking reactions or functional group transformation, and in reactions leading to the formation of crosslinks, where sulfur amino acids, lysine and tyrosine are mainly involved [Davídek et al., 1983]. Hęś et al. [2007, 2012] observed a loss of lysine and methionine in meatballs subjected to severe oxidative stress. Substantial losses of available forms of lysine and methionine at the level of $53 \%$ and $75 \%$ were observed during frozen storage of pork meatballs [Hęś et al., 2007]. Park \& Xiong [2007] have shown a reduction in the quantity and quality of essential amino acids in porcine myofibrillar protein isolate following exposure to different oxidizing environments. Ganhão et al. [2010b], Utrera et al. [2012] and Villaverde et al. [2014] reported losses of tryptophan during processing of porcine patties and fermented sausages. A loss of tryptophan up to $80 \%$ of the initial concentration was also found during frozen storage of beef patties [Utrera et al., 2014ab]. The formation of transverse crosslinks, occurring as a result of the reaction of proteins and amino acids with primary and secondary products of the lipid oxidation, results in a reduction of protein digestibility [Morzel et al., 2006; Santé-Lhoutellier et al., 2008]. The crosslinked polypeptide chains are resistant to the proteolytic activity of enzymes, which leads to a reduction in digestibility and to a reduction of the amount of available amino acids. The products of lipid oxidation also affect the proteins of biological systems, including digestive enzymes and others that partially or completely lose the ability to catalyze a reaction [Chelh et al., 2007; Santé-Lhoutellier et al., 2008]. The oxidation of structural proteins, regardless of reductions in their enzymatic activity, can lead to fragmentation of the particles and formation of new compounds, which may be toxic or carcinogenic [Rice-Evans \& Burdon, 1993]. A high oxidation will induce modifications of the protein structure, thus cross-linking and massive aggregation as well as modification of protease-active sites, all of which result in decreased proteolytic susceptibility and reduced digestibility of meat [Estévez, 2011]. Xiong [2000], Davies [2001], Grune et al. [2004] reported that severe protein oxidation will result in protein of reduced 
susceptibility to digestive enzymes. A semiautomatic flow procedure with photometric detection was employed in digestion studies of whole protein extracts from raw and cooked meat. The results show that meat cooking leads to an important decrease of protein digestibility by proteases of the digestive tract [Gatellier \& Santé-Lhoutellier, 2009]. The authors attributed this effect to protein oxidation-induced changes that occurred during the cooking. Millward et al. [2008] and Boye et al. [2012] have pointed out that processing methods can influence many changes in protein quality, including formation of Maillard compounds, oxidized sulfur amino acids, and cross-linked peptide chains, among others, all of which can limit protein bioavailability.

\section{The technological value of proteins}

Residues of protein-lipid interactions lead to a change in the surface charge of the protein, which in turn affects such properties as solubility, hydrophobicity, gelation or emulsification ability. The crosslinked meat proteins exhibit lower water absorption, lesser sensitivity to proteolytic enzyme activity, which hampers the formation of the desired tenderness and appropriate rheological properties of the product [Xiong et al., 2005; Lund et al., 2011; Xiong, 2000 Estévez, 2011; Utrera \& Estévez, 2012]. Aggregation and polymerization of the protein fraction result in an increase in the content of insoluble substances, which leads to a reduction in the viscosity of the environment. In frozen fish, the content of soluble proteins (globulin) decreases proportionally to an increase in lipid oxidation state [Chelh et al., 2007; Santé-Lhoutellier et al., 2008].

The presence of the products of protein-lipid interaction may lead to a change in the flavor profile and color of the product. The appearance of compounds which deteriorate as well as improve the flavor of the product is possible, giving respectively an undesirable, so-called secondary taste, or neutralizing the rancid odor of oxidized lipids, and/or inducing a new, desirable taste sensation [Chelh et al., 2007]. A particular impact on the changes of sensory properties is given by some condensation products of secondary oxidation products of lipids and proteins, especially macromolecular colored compounds, since they are characterized by properties similar to those of Maillard's reaction products [Chelh et al., 2007]. Both during long-term storage of food products rich in lipids and proteins and also during the processing of the products at elevated temperature (baking, frying), oxidized lipids form brown-colored lipid-protein complexes. This is particularly marked in light-colored products, such as poultry, fish fillets, milk powder, full fat soybean, or freeze-dried meat [Pokorný et al., 1990]. On the surface of white poultry and fish stored in refrigerated conditions, dark spots may occur, which significantly reduce the technological value of these materials. In the case of dried products, hydration ability is reduced.

Proteins, amino acids and compounds formed as a result of the interaction of lipid oxidation products with proteins exhibit antioxidant properties. Generally, it can be assumed that the same reactions, which in protein-lipid food products cause a reduction in the nutritional value or quality due to the modification of the protein fraction, determine the protective effect of peptides on the lipid fraction in the protein-stabi- lized emulsion model systems and depending on the reference system, these changes are determined as either negative or positive. The antioxidant activity of proteins can be considered at three levels: the properties of proteins as polymers of amphiphilic structure, that is hydrophobic-hydrophilic, which determines, among other aspects, the surfactant activity of these compounds [Viljanen, 2005]; antioxidant activity of individual amino acids [Saito et al., 2003; Platt \& Gieseg, 2003; Levine et al., 1996]; and the antioxidant nature of colored macromolecular compounds, which are products of non-enzymatic browning as a result of the interaction of oxidized lipids and proteins [Alaiz et al., 1996, 1997]. Macromolecular compounds formed as a result of condensation between secondary lipid oxidation products and proteins exhibit moderate antioxidant activity [Chelh et al., 2007]. These forms are known as Schiff bases, occurring as a result of the interaction of amino acids containing free amino groups (mostly Lys) with aldehydes in the same reactions where Maillard reaction products are formed. Pyrroles exhibit antioxidant activity dependent on the polarity of the environmental components. Essentially, these compounds result from the negative effects of oxidized lipids on proteins, which are degradation products of proteins, and they are able to reduce oxidative stress. This is possible through the competitive reaction with other nucleophilic compounds in the interaction with reactive oxygen species [Alaiz et al., 1996, 1997; Zamora et al., 1997; Hidalgo et al., 2003]. Comparison of the antioxidant activity of the classical Maillard reaction products with those arising from the protein-lipid interactions indicates no difference in their activity [Alaiz et al., 1997].

\section{THE USE OF ANTIOXIDANT ADDITIVES IN REDUCING THE LOSS OF THE NUTRITIONAL VALUE OF MEAT PROTEINS}

In meat and preserves, which constitute a source of protein of high biological value, protein-lipid interactions lead to extremely negative consequences. Due to the relatively high lipid content and thus lower oxidative stability, these interactions easily occur, and thus significantly reduce the nutritional and technological value of these products [Hęs et al., 2007; Santé-Lhoutellier et al., 2008]. Attempts are being made to restrict lipid oxidation processes in food, among others through the use of antioxidants. Frequently published studies suggest the limitation of the use of synthetic antioxidants due to their potential toxicity and carcinogenicity [Bauer et al., 2001; Koltover, 2010; U.S. National Library of Medicine, 2010]. Also, consumer preferences indicate a greater interest in food products with the addition of compounds derived from natural sources [Karre et al., 2013]. The action of an antioxidant is the more effective, the sooner it begins to act in the system. Therefore, it is advisable to add antioxidants at the initial stages of food processing [Gramza-Michałowska et al., 2011]. The courses of antioxidant activity are varied and may be based on: inhibition of the autoxidation chain at any of these stages, i.e. initiation, propagation and termination, prevention of initiation by binding the substrate (ROS- the so-called reactive oxygen species) or neutralization of compounds accelerating the oxidation process (UV-Vis radiation, 
transition metal ions, lipoxygenase), free radical scavenging, decomposition of the reactive products of lipid oxidation (hydroperoxides and non-radical substances) or the formation of the protective layer on the surface of the interface in multiphase systems [Brewer, 2011]. Some plant extracts containing phenolic compounds were reported to inhibit both lipid oxidation and deterioration of nutritional quality of meat proteins [Hęś et al., 2007; Ganhão et al., 2010b]. Phenolic compounds were suggested to act against oxidation-induced damage of myofibrillar protein by two mechanisms: metal chelation (leading to inactivation of nonheme iron prooxidant effect) and radical scavenging (they could be scavengers of iron- and lipid-mediated reactive oxidant species) [Estévez et al., 2008]. A rich source of these substances are vegetables, fruits, seeds of various plants, some cereals, wine, tea, coffee, fruit juices and many spices [Shahidi \& Zhong, 2010]. Numerous national and international studies show that no compounds have as yet been identified which are more active than tocopherols or rosemary and sage, the safe use of which in food is also the least questioned [Cuvelier et al., 1996]. Main components of antioxidative properties in the case of rosemary and sage are carnosic acid and carnosol, while in the case of thyme it is p-cymeno-2,3-diol (Table 3). Carnosic acid from rosemary protects against oxidation not only full value polyunsaturated fatty acids, but also $\alpha$-tocopherol. The source of polyphenolic compounds are also tea leaves (Camelia sinensis). The most interesting group of tea polyphenols includes catechins and phenolic acids (Table 3 ).

Rosemary, marjoram, thyme and garlic are also often used in different substrates of model systems and meat processing (Table 4). These spices, due to their long tradition of safe consumption and the content of antioxidant substances in appropriate proportions for humans, may be useful in the prevention of degenerative diseases [Dauchet et al., 2009; Vainio \& Weiderpass, 2006]. By reducing the amount of lipid oxidation products, they can also shape the nutritional value of meat products, e.g. reduce the loss of vitamin B1 or the nutritional value of proteins. During storage of meatballs from ground pork without the addition of antioxidants, a significant decrease has been found in the availability of lysine and methionine and also protein digestibility in vitro. The addition of antioxidants significantly decreased the quantitative loss of available lysine and methionine and inhibited the decrease in digestibility. The highest ability to reduce the nutritional value of the protein was demonstrated by BHT synthetic antioxidant and green tea extract (among natural additives) [Hęś et al., 2007]. During storage of experimentally-prepared raw sausages, a decrease has been found in the content of available lysine and methionine. The initial content of lysine in the raw sausages was 5.15-5.26 g per $100 \mathrm{~g}$ protein. The largest differences in the proportion of this component between the first and the last day of storage have been observed for controls above $36 \%$. Decreases in methionine content are distributed similarly. In a sample without the addition of antioxidant, the content of amino acid decreases by almost $37 \%$ as compared to the initial value. The addition of antioxidants significantly reduced quantitative losses of available lysine and methionine. Natural antioxidants exhibited a lower capacity to reduce losses of nutritive value of protein than it was found
TABLE 3. Antioxidants isolated from herbs, spices and teas.

\begin{tabular}{|c|c|c|}
\hline $\begin{array}{l}\text { Species } \\
\text { (Systematic names) }\end{array}$ & Constituents & References \\
\hline $\begin{array}{l}\text { Rosemary } \\
\text { (Rosemarinus } \\
\text { officinalis) }\end{array}$ & $\begin{array}{l}\text { Carnosic acid, } \\
\text { carnosol, rosmarinic } \\
\text { acid, rosmanol }\end{array}$ & $\begin{array}{l}\text { Zhang et al. [2012]; } \\
\text { Borrás-Linares } \\
\text { et al. } \text { [2014] }\end{array}$ \\
\hline $\begin{array}{l}\text { Sage } \\
\text { (Salvia officinalis) }\end{array}$ & $\begin{array}{l}\text { Carnosol, carnosic } \\
\text { acid, rosmanol, } \\
\text { rosmarinic acid }\end{array}$ & $\begin{array}{l}\text { Cuvelier et al. [1996]; } \\
\text { Miura et al. 2002; } \\
\text { Abreu et al. [2008] }\end{array}$ \\
\hline $\begin{array}{l}\text { Oregano } \\
\text { (Origanum } \\
\text { vulgare) }\end{array}$ & $\begin{array}{c}\text { Derivatives of phenolic } \\
\text { acids, flavonoids, } \\
\text { tocopherols }\end{array}$ & $\begin{array}{l}\text { Vekiari et al. [1993]; } \\
\text { Lagouri \& Boskou } \\
\text { [1996]; Muchuweti } \\
\text { et al. }[2007]\end{array}$ \\
\hline $\begin{array}{l}\text { Thyme } \\
\text { (Thymus vulgaris) }\end{array}$ & $\begin{array}{l}\text { Thymol, carvacrol, } \\
\text { p-cymeno-2,3-diol, } \\
\text { biphenyls, flavonoids }\end{array}$ & $\begin{array}{l}\text { Miura et al. [2002]; } \\
\text { Lee et al. [2005] }\end{array}$ \\
\hline $\begin{array}{l}\text { Garlic } \\
\text { (Allium sativum) }\end{array}$ & $\begin{array}{l}\text { Flavonoids, sulfur } \\
\text { containing compounds }\end{array}$ & $\begin{array}{c}\text { Amagase [2006]; } \\
\text { Gorinstein et al. [2008] }\end{array}$ \\
\hline $\begin{array}{l}\text { Marjoram } \\
\text { (Majorana } \\
\text { hortensis) }\end{array}$ & Flavonoids & $\begin{array}{l}\text { Dolci \& Tira } \\
\text { [1980]; Muchuweti } \\
\text { et. al. }[2007]\end{array}$ \\
\hline $\begin{array}{l}\text { Ginger } \\
\text { (Zingiber } \\
\text { officinale) }\end{array}$ & $\begin{array}{l}\text { Gingerol-related } \\
\text { compounds, } \\
\text { diarylheptanoids }\end{array}$ & $\begin{array}{l}\text { Kikuzaki et al. [1994]; } \\
\text { El-Ghorab et al. [2010] }\end{array}$ \\
\hline $\begin{array}{l}\text { Black pepper } \\
\text { (Piper nigrum) }\end{array}$ & $\begin{array}{l}\text { Phenolic amides, } \\
\text { flavonoids }\end{array}$ & $\begin{array}{l}\text { Kapoor et al. [2009]; } \\
\text { Liang et al. [2010] }\end{array}$ \\
\hline $\begin{array}{l}\text { Red pepper } \\
\text { (Capsicum annum) }\end{array}$ & Capsaicin & $\begin{array}{l}\text { Nakatani [1992]; Al } \\
\text { Othman et al. [2011] }\end{array}$ \\
\hline $\begin{array}{l}\text { Chili pepper } \\
\text { (Capsicum } \\
\text { frutescence) }\end{array}$ & Capsaicin, capsaicinol & $\begin{array}{l}\text { Nakatani [1992]; Al } \\
\text { Othman et al. [2011] }\end{array}$ \\
\hline $\begin{array}{l}\text { Tumeric } \\
\text { (Curcuma } \\
\text { domestica) }\end{array}$ & Curcumins & $\begin{array}{c}\text { Masuda \& Jitoe } \\
\text { [1994]; Priyadarsini } \\
\text { et al. }[2003]\end{array}$ \\
\hline $\begin{array}{l}\text { Green tea } \\
\text { (Camelia sinensis) }\end{array}$ & Catechins & $\begin{array}{c}\text { Graham [1992]; } \\
\text { Gramza et al. [2005] }\end{array}$ \\
\hline $\begin{array}{l}\text { Black tea } \\
\text { (Camelia } \\
\text { assamica) }\end{array}$ & $\begin{array}{l}\text { Theaflavines, } \\
\text { thearubigins }\end{array}$ & $\begin{array}{l}\text { Kiehne \& Engelhardt } \\
\text { [1996]; Henning } \\
\text { et al. [2003] }\end{array}$ \\
\hline
\end{tabular}

for BHT [Pyrcz et al., 2007]. The addition of ethanolic flaxseed extracts (EFEs) significantly limited lipid oxidation in stored meatballs and burgers [Waszkowiak et al., 2014]. Moreover, the extracts reduced changes in thiamine and available lysine content, as well as protein digestibility, during storage time. The effect of EFE addition on available methionine retention was limited. In turn, the utilization of wheat fiber as an iodine salt carrier had a significant effect on the reduction of lysine losses. No protective properties were found for the wheat fiber or soy protein isolate towards methionine [Hęś et al., 2012]. Litchi flowers may be an effective natural antioxidant to reduce lipid and protein oxidation for frozen cooked meat products [Ding et al., 2015]. Ganhão et al. [2010b] reported that using extracts from dog roses, common hawthorns, elmleaf blackberries, and arbutus berries during processing and storage of burger patties resulted in the inhibition of muscle protein oxidation. The application of fruit extracts as antioxidant and functional ingredients may increase the nutritional quality of the meat products. Utrera et al. [2012] came to the same conclusion when they studied the effects of the addition of a phenolicrich avocado extract on protein oxidation in porcine patties subjected to cooking and chilled storage. Hęś et al. [2011] determined the effect of added ethanolic extracts of thyme, 
TABLE 4. Antioxidant activity of plant material and its preparations in different substrates.

\begin{tabular}{|c|c|c|c|}
\hline Sample & Substrate & Antioxidant activity & References \\
\hline Plant materials & Lard & Rosemary $>$ sage $>$ nutmeg $>$ white pepper $>$ marjoram & Palitzsch et al. [1969] \\
\hline Plant materials & Lard & Rosemary $>$ sage $>$ oregano $>$ nutmeg $>$ thyme & Chipault et al. [1952] \\
\hline Dichloromethane extract & Lard & Ginger $>$ clove $>$ pepper $>$ cinnamon $>$ fennel & He et al. [1998] \\
\hline Commercial product & Lard & Rosemary $>$ sage $>$ marjoram $>$ mace $>$ black pepper & Palitzsch et al. [1974] \\
\hline Methanol extract & Lard & $\begin{array}{c}\text { Oregano }>\text { thyme }>\text { dittany }>\text { marjoram }> \\
\text { spearmint }>\text { lavender }>\text { basil }\end{array}$ & Economou et al. [1991] \\
\hline Plant materials & $\begin{array}{l}\text { Oil-in-water- } \\
\text { emulsion }\end{array}$ & Clove $>$ turmeric $>$ allspice $>$ mace $>$ rosemary & Chipault et al. [1955] \\
\hline Ethanol extracts & $\begin{array}{l}\text { Low-erucic } \\
\text { rapeseed oil }\end{array}$ & Sage $>$ thyme $>$ oregano $>$ juniper & Takacsová [1995] \\
\hline Plant materials & Sausage & $\begin{array}{c}\text { Sage }>\text { rosemary }>\text { paprika }>\text { marjoram }> \\
\text { aniseed }\end{array}$ & Gerhard \& Böhm [1980] \\
\hline Plant materials & $\begin{array}{l}\text { Minced chicken } \\
\text { meat }\end{array}$ & Marjoram $>$ caraway $>$ peppermint $>$ clove & Abd El-Alim et al. [1999] \\
\hline Ethanol extracts & $\begin{array}{l}\text { Minced chicken } \\
\text { meat }\end{array}$ & Caraway $>$ wild marjoram $>$ cinnamon & Abd El-Alim et al. [1999] \\
\hline Plant materials & Chicken burger & Thyme $>$ sage $>$ rosemary $>$ marjoram $>$ black seeds & Darwish et al. [2012] \\
\hline $\begin{array}{l}\text { Green tea and thyme } \\
\text { oil extracts }\end{array}$ & $\begin{array}{l}\text { Luncheon } \\
\text { rolls meat }\end{array}$ & $\begin{array}{c}\text { Green tea and thyme oil extracts }>\text { green } \\
\text { tea extract }>\text { thyme oil extract }\end{array}$ & Abu-Salem et al. [2011] \\
\hline Water extracts & Beef marinades & $\begin{array}{c}\text { Marjoram }>\text { thyme }>\text { dry red wine }>\text { garlic }> \\
\text { horseradish }>\text { lime-tree honey }\end{array}$ & Istrati et al. [2013] \\
\hline Ethanol extracts & Fish & $\begin{array}{l}\text { Clove }>\text { thyme }>\text { oregano }(\mathrm{PV})^{\mathrm{a}} \\
\text { Oregano }>\text { clove }>\text { thyme }(\mathrm{TBA})^{\mathrm{b}}\end{array}$ & Bensid et al. [2014] \\
\hline
\end{tabular}

${ }^{\mathrm{a} P V}$ - peroxide value (meq/kg of fat), ${ }^{\mathrm{b}} \mathrm{TBA}$ - thiobarbituric acid value (mg malonaldehyde/kg of sample).

green tea, and commercial extract of rosemary and BHT on the oxidation stability and the reduction of nutritional losses of lyophilized meat. None of the additives showed any protective activity as regards the exogenous amino acids. The highest loss of the available lysine was found in a sample with rosemary extract added; it amounted to nearly $51 \%$. The highest decrease in the content of available methionine, amounting to about $41 \%$, was reported in the samples with the thyme extract applied. The protective activity of anti-oxidants was found as regards the thiamine. In the samples with BHT and rosemary additives, significantly lower losses of this vitamin were found compared to the control sample.

Antioxidant efficiency of the phenolic compounds in meat products depends on numerous factors, e.g. their structure, localization and interaction with meat proteins [Estevez \& Heinonen, 2010; Lund et al., 2011]. Unfortunately, in the literature there is a lack of information on the effects of plant extracts on the oxidative stability of lipids in foods, including meat products. The activity of antioxidants may be influenced by technological processes, which food products are subjected to, including culinary processing. These processes may lead to increased antioxidant activity, and also to their destruction. Therefore, it is important to understand this impact, which will allow us to predict the real effectiveness of the antioxidant activity in the prepared food products. In meat products, both whole spices (additionally forming the flavor characteristics of the product), multicomponent specimens obtained from sources rich in antioxidants, as well as from isolated, pure compounds are used. However, in physical terms, these specimens may be obtained as, inter alia, extracts and isolates in liquid, powdered, paste, dried products or microencapsulated specimens. A comparison of the antioxidant activity of some of the above-mentioned forms of additives has shown that the best properties are attributed to the extracts, then freeze-dried products, dried products obtained by desiccation in an oven and - finally - ground fresh spices [Henning et al., 2011; Raksakantong et al., 2011]. The use of antioxidants in the form of extracts and purified extracts is expensive and requires a laboratory facility. On the other hand, a broad spectrum of plant material extraction methods allow the selection of appropriate methods taking into account the nature of the isolated chemical substances; thereby, it is possible to isolate the compound or a group of compounds in pure form. The loss of activity as a result of the production is small and the obtained extracts exhibit a high efficiency of antioxidant activity, which does not change during storage. In addition, the products obtained in this way are standardized and are free from physical and microbiological impurities. A characteristic feature of antioxidants is that they act at low concentrations, usually $0.001-0.1 \%$, while an overly high content of compounds susceptible for oxidation can exhibit prooxidative activity. Accordingly, the concentration of the additive of natural antioxidants is established at a low level, based on the following indicators: the content of the active compounds in the desired raw material, moderate activity of the extract tested in model systems or pilot experiments, the form of the plant material, the methods and parameters for obtaining an extract; the quantity (mass) and the size of the product and the resulting heat treatment parameters, taking into account the loss of antioxidants. 
Antioxidants do not exhibit the same activity in a variety of systems containing lipids. It has been found that polar antioxidants are more active in lipids in a mass state, while non-polar ones in emulsified systems. The paradox of polarity is often explained by antioxidant properties at the interface and their affinity to different phases [Cuvelier et al., 2000; Frankel et al., 1994]. Studies have shown that in multiphase systems the concentration of antioxidants in different regions depends on their polarity and solubility [Huang et al., 1996]. There are known synergistic and antagonistic interactions with certain compounds, which can be defined as "the effect of the mixture". The results of the studies conducted by Cuvelier et al. [1996] and Arts et al. [2002] confirm that, in the determination of the properties of the extracts, one should not take into account interactions occurring within only the proportion of the phenolic compounds. Berry raw materials rich in phenolic compounds may provide antioxidant protection toward both lipid and protein oxidation resulting in a liposome model system. It was found that the antioxidant activity depends on the individual berry phenolic components profile, including anthocyanins, ellagitannins, and proanthocyanins [Viljanen et al., 2004].

Better understanding of these interactions will enable extracts with more effective antioxidant properties to be obtained. However, it should also be noted that there are few studies suggesting pro-oxidative properties of some polyphenols. Their activity depends on many factors, such as reduction potential, metal chelating ability, $\mathrm{pH}$ of the environment, solubility, bioavailability and stability in tissues and cells [Decker, 1997]. Similarly to the situation in food, oxidation reactions also occur in living organisms. For humans, oxidation is a metabolic process, which simultaneously leads to the inevitable formation of radicals which in further steps may initiate damage in cell membranes, modify functions of low density lipoprotein (LDL), change platelet function, and induce DNA mutations [Kanner, 2007]. Natural antioxidants may exhibit health benefits, acting as prophylactic agents. The above-mentioned effects can be achieved by reducing the amount of lipid oxidation products in food and transfer of the antioxidant activity to the human body [Duthie et al., 2013; Hooper \& Cassidy, 2006]. Current dietary recommendations suggest increased intake of food of plant origin in the diet, resulting in an increase in the level of polyphenols and phytosterols in the blood, which can affect the biological properties of the cells [Martin et al., 2013]. Trials are still in progress in the search for new sources of these substances, the availability of which in everyday food could also affect the inhibition of negative processes in the human organism [Augustyniak et al., 2010]. Therefore, it seems appropriate to conduct research towards search for, and isolation, characterization and determination of biologically-active compounds of plant origin, which are harmless and non-toxic to humans, with high antioxidant activity when added to food. The possibility of the application of these compounds in food technology can thus contribute to the improvement of the quality and safety of food products and the production of a substantial group of functional foods with high oxidative stability and high nutritional value.

\section{CONCLUSION}

Lipid oxidation and subsequent protein-lipid interactions are the main cause of the quality deterioration of numerous products, including meat. These reactions occur with a high intensity, even in refrigeration and freezing temperature storage, and lead to a reduction in the nutritional value of meat products, and as a result, toxic and allergenic compounds may arise. Therefore, the priority is to maximize the reduction of the oxidative metabolism of lipids. The use of plant extracts as antioxidants in meat products is gaining popularity and is widely accepted by consumers, as food additives derived from natural raw materials are known to be safe.

In studies, in which the purpose of the use of natural antioxidants was examined, the additional effect of shaping the nutritional value of food has thus far been ignored.

Nutritional and health aspects shed new light on the purpose of the use of antioxidants in food technology and give rise to a broad-based introduction into nutritional practice of new foods rich or enriched in natural antioxidants.

\section{RESEARCH FUNDING}

This work was financed by the Ministry of Science and Higher Education in 2006-2009, research project number N312 025 31/2049.

\section{CONFLICT OF INTEREST}

None declared.

\section{REFERENCES}

1. Aalhus J.L., Dugan M.E.R., Spoilage, factors affecting (b) oxidative and enzymatic. 2014, in: Encyclopedia of meat sciences (eds. C. Devine, M. Dikeman). Academic Press, London, UK, pp. 392-400.

2. Abd El-Alim S.S.L., Lugasi A., Hovari J., Dworschak E., Culinary herbs inhibit lipid oxidation in raw and cooked minced meat patties during storage. J. Sci. Food Agric., 1999, 79, 277-285.

3. Abreu M.E., Muller M., Alegre L., Munné-Bosch S., Phenolic diterpene and $\alpha$-tocopherol contents in leaf extracts of 60 Salvia species. J. Sci. Food Agric., 2008, 88, 2648-2653.

4. Abu-Salem F.M., Abou-Arab E.A., Ibrahim H.M., Abou-Arab A.A., Effect of adding green tea extract, thyme oil and/or their combination to luncheon roll meat during refrigerate storage. J. Am. Sci., 2011, 7(7), 538-548.

5. Adams A., Kitryte V., Venskutonis R., De Kimpe N., Formation and characterization of melanoidin-like polycondensation products from amino acids and lipid oxidation products. Food Chem., 2009, 115, 904-911.

6. Al Othman A.A., Ahmed Y.B.H., Habila M.A., Ghafar A.A., Determination of capsaicin and dihydrocapsaicin in Capsicum fruit samples using High Performance Liquid Chromatography. Molecules, 2011, 16, 8919-8929.

7. Alaiz M., Zamora R., Hidalgo F.J., Contribution of the formation of oxidized lipid/amino acid reaction products to the protective role of amino acids in oils and fats. J. Agric. Food Chem., 1996, 44, 1890-1895. 
8. Alaiz M., Hidalgo F.J., Zamora R., Comparative antioxidant activity of Maillard- and oxidized lipid-damaged bovine serum albumin. J. Agric. Food Chem., 1997, 45, 3250-3254.

9. Amagase H., Clarifying the real bioactive constituents of garlic. J. Nutr., 2006, 136 (Suppl. 3), 716S-725S.

10. Arts M.J.T.J., Haenen G.R.M.M., Wilms L.C., Beetstra S.A.J.N., Heijnen C.G.M., Voss H., Bast A., Interactions between flavonoids and proteins: effect on the total antioxidant capacity J. Agric. Food Chem., 2002, 50, 1184-1187.

11. Augustyniak A., Bartosz G., Cipak A., Duburs G., Horáková L., Łuczaj W., Majekova M., Odysseos A.D., Rackova L., Skrzydlewska L. et al., Natural and synthetic antioxidants: An updated review. Free Radic. Res., 2010, 44, SI, 1216-1262.

12. Bauer A.K., Dwyer-Nield L.D., Hankin J.A., Murphy R.C., Malkinson A.M., The lung tumor promoter, butylated hydroxytoluene (BHT), causes chronic inflammation in promotion sensitive $\mathrm{BALB} / \mathrm{cByJ}$ mice but not in promotion-resistant CXB4 mice. Toxicology, 2001, 169, 1, 1-15.

13. Bensid A., Ucar Y., Bendeddouche B., Özogul F., Effect of the icing with thyme, oregano and clove extracts on quality parameters of gutted and beheaded anchovy (Engraulis encrasicholus) during chilled storage. Food Chem., 2014, 145, 681-686.

14. Borrás-Linares I., Stojanović Z., Quirantes-Piné R., ArráezRomán D., Švarc-Gajić J., Fernández-Gutiérrez A., Segura-Carretero A., Rosmarinus officinalis leaves as a natural source of bioactive compounds. Int. J. Mol. Sci., 2014, 15, 20585-20606.

15. Boye J., Wijesinha-Bettoni R., Burlingame B., Protein quality evaluation twenty years after the introduction of the protein digestibility corrected amino acid score method. Br. J. Nutr., 2012, 108, S183-211.

16. Brewer M.S., Natural antioxidants: sources, compounds, mechanisms of action, and potential applications. Compr. Rev. Food Sci. F., 2011, 10, 221-247.

17. Chelh I., Gatellier P., Santé-Lhoutellier V., Characterization of fluorescent Schiff bases formed during oxidation of pig myofibrils. Meat Sci., 2007, 76, 210-215.

18. Chipault J.R., Mizuno G.R., Hawkins J.M., Lundberg W.O., The antioxidant properties of natural spices. Food Res., 1952, $17,46-55$.

19. Chipault J.R., Mizuno G.R., Hawkins J.M., Lundberg W.O., Antioxidant properties of spices in oil-in-water emulsion. Food Res., 1955, 20, 443-448.

20. Chowdhury S.K., Eshraghi J., Wolfe H., Forde D., Hlavac A.G., Johnston D., Mass spectrometric identification of amino acid transformation during oxidation of peptides and proteins: modifications of methionine and tyrosine. Anal. Chem., 1995, 67, 390-398.

21. Contini C., Alvarez R., O’Sullivana M., Dowling D.P., Gargan S.O., Monahan F.J., Effect of an active packaging with citrus extract on lipid oxidation and sensory quality of cooked turkey meat. Meat Sci., 2014, 96, 1171-1176.

22. Cuvelier M.E., Richard H., Berset C., Antioxidative activity and phenolic composition of pilot-plant and commercial extracts of sage and rosemary. J. Am. Oil Chem. Soc., 1996, 73, 645-652.

23. Cuvelier M.E., Bondet V., Berset C., Behavior of phenolic antioxidants in a partitioned medium: structure-activity relationship. J. Am. Oil Chem. Soc., 2000, 77, 819-823.

24. Darwish S.M.I., El-Geddawy M.A.H., Khalifa R.M.B., Rewaa A.A., Mohamed R.A.A., Antioxidant activities of some spices and herbs added to frozen chicken burger. Front. Sci., 2012, 2(6), 144-152.

25. Dauchet L., Amouyel P., Dallongeville J., Fruits, vegetables and coronary heart disease. Nat. Rev. Cardiol., 2009, 6, 599-608.

26. Davídek J., Janíček G., Pokorný J., Chemie potravin. 1983, SNTL/ALFA, Praha.

27. Davies K.J.A., Degradation of oxidized proteins by the 20 S proteasome. Biochimie, 2001, 83, 301-310.

28. Decker E.A., Phenolics: prooxidants or antioxidants? Nutr. Rev., 1997, 55, 396-398.

29. Ding Y., Wang S.-Y., Yang D.-J., Chang M.-H., Chen Y.-C., Alleviative effects of litchi (Litchi chinensis Sonn.) flower on lipid peroxidation and protein degradation in emulsified pork meatballs. J. Food Drug Anal., 2015, 23, 501-508.

30. Dolci M., Tira S., Flavonoids of Majorana hortensis. Riv. Ital. Essenze Profumi Piante Off, Aromat. Syndets Saponi Cosmet. Aerosols, 1980, 62, 131-132.

31. Duthie G., Campbell F., Bestwick Ch., Stephen S., Russell W., Antioxidant effectiveness of vegetable powders on the lipid and protein oxidative stability of cooked turkey meat patties: implications for health. Nutrients, 2013, 5(4), 1241-1252.

32. Economou K.D., Oreopoulou V., Thomopoulos C.D., Antioxidant activity of some plant extracts of the family Labiate. J. Am. Oil Chem. Soc., 1991, 68, 109-113.

33. El-Ghorab H., Nauman M., Anjum F.M., Hussain S., Nadeem M., Comparative study on chemical composition and antioxidant activity of ginger (Zingiber officinale) and cumin (Cuminum cyminum). J. Agric. Food Chem., 2010, 58(14), 8231-8237.

34. Estévez M., Protein carbonyls in meat systems: a review. Meat Sci., 2011, 89, 259-279.

35. Estévez M., Heinonen M., Effect of phenolic compounds on the formation of $\alpha$-aminoadipic and $\gamma$-glutamic semialdehydes from myofibrillar proteins oxidized by copper, iron, and myoglobin. J. Agric. Food Chem., 2010, 58, 4448-4455.

36. Estévez M., Kylli P., Puolanne E., Kivikari R., Heinonen M., Oxidation of skeletal muscle myofibrillar proteins in oil-in-water emulsion: interaction with lipids and effect of selected phenolic compounds. J. Agric. Food Chem., 2008, 56, SI, 10933-10940.

37. Frankel E.N., Huang S.W., Kanne J., German J.B., Interfacial phenomena in the evaluation of antioxidants: bulk oils vs emulsions. J. Agric. Food Chem., 1994, 42, 1054-1059.

38. Fuentes V., Estévez M., Ventanas J., Ventanas S., Impact of lipid content and composition on lipid oxidation and protein carbonylation in experimental fermented sausages. Food Chem., 2014, $147,70-77$.

39. Ganhão R., Morcuende D., Estévez M., Protein oxidation in emulsified cooked burger patties with added fruit extracts: influence on colour and texture deterioration during chill storage. Meat Sci., 2010a, 85, 402-409.

40. Ganhão R., Morcuende D., Estévez M., Tryptophan depletion and formation of $\alpha$-aminoadipic and $\gamma$-glutamic semialdehydes in porcine burger patties with added phenolic-rich fruit extracts. J. Agric. Food Chem., 2010b, 58, 3541-3548.

41. Gatellier P., Santé-Lhoutellier V., Digestion study of proteins from cooked meat using an enzymatic microreactor. Meat Sci., 2009, 81, 405-409.

42. Gatellier P., Kondjoyan A., Portanguen S., Gréve E., Yoon K., Santé-Lhoutellier V., Determination of aromatic amino acid content in cooked meat by derivative spectrophotometry: Impli- 
cations for nutritional quality of meat. Food Chem., 2009, 114 1074-1078.

43. Gerhardt U., Böhm A., Redox behavior of spices in meat products. Fleischwirtschaft, 1980, 60, 1523-1526.

44. Gorinstein M., Leontowicz H., Leontowicz M., Namiesnik J., Najman K., Drzewiecki J., Martincová O., Katrich E., Trakhtenberg S., Comparison of the main bioactive compounds and antioxidant activities in garlic and white and red onions after treatment protocols. J. Agric. Food Chem., 2008, 56(12), 4418-4426.

45. Graham H.N., Green tea composition, consumption and polyphenol chemistry. Prev. Med., 1992, 21, 334-350.

46. Gramza A., Korczak J., Amarowicz R., Tea polyphenols - their antioxidant properties and biological activity - a review. Pol. J. Food Nutr. Sci., 2005, 14/55, 3, 219-235.

47. Gramza-Michałowska A., Sidor A., Hęś M., Herb extract influence on the oxidative stability of selected lipids. J. Food Biochem., 2011, 35(6), 1723-1736.

48. Gray J.I., Gomaa E.A., Buckley D.J., Oxidative quality and shelf life of meats. Meat Sci., 1996, 43, 111-123.

49. Grune T., Jung T., Merker K., Davies K.J.A., Decreased proteolysis caused by protein aggregates, inclusion bodies, plaques, lipofuscin, ceroid, and 'aggresomes' during oxidative stress, aging, and disease. Int. J. Biochem. Cell B., 2004, 36, 2519-2530.

50. Hassan H.A., Lipid peroxidation end-products as a key of oxidative stress: Effect of antioxidant on their production and transfer of free radicals. 2012, in: Lipid Peroxidation (ed. A. Catala). Tech Publishing, Croatia, pp. 63-87.

51. He W., Li Y., Li L., Guo J., Spice antioxidants for use in oil. Zhongguo Tiaoweipin, 1998, 7, 12-15.

52. Henning S.M., Fajardo-Lira C., Lee H.W., Youssefian A.A., Vay L.W., Go V.L.W., Heber D., Catechin content of 18 teas and a green tea extract supplement correlates with the antioxidant capacity. Nutr. Cancer., 2003, 45(2), 226-235.

53. Henning S.M., Zhang Y.J., Seeram, N.P., Lee R.P., Wang P.W., Bowerman S., Heber D., Antioxidant capacity and phytochemical content of herbs and spices in dry, fresh and blended herb paste form. Int. J. Food Sci. Nutr., 2011, 62, 3, 219-225

54. Hęś M., Gramza-Michałowska A., Effect of plant extracts on lipid oxidation and changes in nutritive value of protein in frozenstored meat products. J. Food Process. Pres., 2016, doi:10.1111/ jfpp.12989 (in press).

55. Hęś M., Gramza A., Korczak J., Changes of lipid oxidation degrees and their influence on protein nutritive value of frozen meat products. Pol. J. Food Nutr. Sci., 2007, 57, 323-328.

56. Hęś M., Jeżewska M., Szymandera-Buszka K., Gramza-Michałowska A., Effect of antioxidant additives on nutritive value of dried meat. Żywność. Nauka. Technologia. Jakość, 2011, 5(78), 94-106 (in Polish; English abstract).

57. Hęś M., Waszkowiak K., Szymandera-Buszka K., The effect of iodine salts on lipid oxidation and changes in nutritive value of protein in stored processed meats. Meat Sci., 2012, 92, 139-143 .

58. Hidalgo F.J., Nogales F., Zamora R., Effect of the pyrrole polymerization mechanism on the antioxidative activity of nonenzymatic browning reactions. J. Agric. Food Chem., 2003, 51, 5703-5708.

59. Hoffmann K., Nutritional value of proteins and protein requirements of people with special reference to meat proteins. Mitteilungsbl. Bundesanst. Fleischforsch, 1993, 32, 422-429.
60. Hooper L., Cassidy A., A review of the health care potential of bioactive compounds. J. Sci. Food Agric., 2006, 86, 1805$-1813$.

61. Huang S.W., Frankel E.N., Schwarz K., Aeschbach R., German J.B., Antioxidant activity of carnosic acid and methyl carnosate in bulk oils and oils-in-water emulsions. J. Agric. Food Chem., 1996, 44, 2951-2956.

62. Istrati D., Vizireanu C., Dima F., Garnai M., Evaluation of polyphenols and flavonoids in marinades used to tenderize beef muscle. J. Agroalimentary Process. Technol., 2013, 19(1), 116-121.

63. Kanner J., Dietary advanced lipid oxidation end products are risk factors to human health. Mol. Nutr. Food Res., 2007, 51(9),1094-1101.

64. Kapoor I.P.S., Singh B., Singh G., Heluani C.S. de Lampasona M.P., Catalan C.A.N., Chemical and in vitro antioxidant activity of volatile oil and oleoresins of black pepper (Piper nigrum). J. Agric. Food Chem., 2009, 57(12), 5358-5364.

65. Karel M., Schaich K., Roy R.B., Interaction of peroxidizing methyl linoleate with some proteins and amino acids. J. Agric. Food Chem., 1975, 23, 159-163.

66. Karre L., Lopez K., Getty K.J., Natural antioxidants in meat and poultry products. Meat Sci., 2013, 94(2), 220-227.

67. Kiehne A., Engelhardt U., Thermospray LC-MS analysis of various groups of polyphenols in tea. II: chlorogenic acids, theaflavins and thearubigins. Z. Lebensm. Unters. Forsch., 1996, 202(4), 299-302.

68. Kikuzaki H., Kawasaki Y., Nakatani N., Structure of the antioxidative compounds in ginger. 1994, in: Food Phytochemicals for Cancer Prevention II Teas, Spices and Herbs (eds. C-T. Ho, T. Osawa, M-T. Huang, R.T. Rosen). ACS Symposium Series No. 547. ACS Press, Washington DC, pp. 237-247.

69. Koltover V.K., Antioxidant biomedicine: from free radical chemistry to systems biology mechanisms. Russian Chemical Bulletin, Int. Ed., 2010, 59(1), 37-42.

70. Lagouri V., Boskou, D., Nutrient antioxidant in oregano. Int. J. Food Sci. Nutr., 1996, 47, 493-497.

71. Lee A.J., Umano K., Shibamoto T., Lee K.G., Identification of volatile components in basil (Ocimum basilicum L.) and thyme leaves (Thymus vulgaris L.) and their antioxidant properties. Food Chem., 2005, 91(1), 131-137.

72. Levine R.L., Mosoni L., Berlett B.S., Stadtman E.R., Methionine residue as endogenous antioxidants in protein. Proc. Nat. Ac. Sci. USA, 1996, 93, 15036-15040.

73. Liang R.J., Shi S.D., Ma Y.J., Analysis of volatile oil composition of the peppers from different production areas. Med. Chem. Res., 2010, 19(2), 157-165.

74. Lund M.N., Heinonen M., Baron C.P., Estévez M., Protein oxidation in muscle food: A review. Mol. Nutr. Food Res., 2011, 55, 83-95.

75. Martin C., Zhang Y., Tonelli Ch., Petroni K., Plants, diet, and health. Annu. Rev. Plant Biol., 2013, 64, 19-46.

76. Masuda T., Jitoe A., Antioxidative and anti-inflammatory compounds from tropical gingers: isolation, structure determination, and activities of cassumunins A, B and C, new complex curcuminoids from Zingiber cassumunar. J. Agric. Food Chem., 1994, 42, 1850-1856.

77. Mercier Y., Gatellier P., Renerre M., Lipid and protein oxidation in vitro, and antioxidant potential in meat from Charolais cows finished on pasture or mixed diet. Meat Sci., 2004, 66, 467-473. 
78. Millward D.J., Layman D.K., Tomé D., Schaafsma G., Protein quality assessment: impact of expanding understanding of protein and amino acid needs for optimal health. Am. J. Clin. Nutr., 2008, 87, 1576S-1581S.

79. Miura K., Kikuzaki H., Nakatani N., Antioxidant activity of chemical components from sage (Salvia officinalis L.) and thyme (Thymus vulgaris L.) measured by the oil stability index method. J. Agric. Food Chem., 2002, 50(7), 1845-1851.

80. Morrison R.T., Boyd R.N., Organic Chemistry. 1990, Allyn and Bacon, Inc., Boston, Massachusetts 02210. Copyright for Polish edition by Państwowe Wydawnictwo Naukowe, Warszawa (in Polish).

81. Morrissey P.A., Sheehy P.J.A., Galvin K., Kerry J.P., Buckley D.J., Lipid stability in meat and meat products. Meat Sci., 1998, 49, S73-S86.

82. Morzel M., Gatellier P.H., Sayd T., Renerre M., Laville E., Chemical oxidation in decreases proteolytic susceptibility of skeletal muscle proteins. Meat Sci., 2006, 73, 536-543.

83. Muchuweti M., Kativu E., Mupure C.H., Chidewe C., Ndhlala A.R., Benhura M.A.N., Phenolic composition and antioxidant properties of some spices. Am. J. Food Tech., 2007, 2(5), 414-420 .

84. Nakatani N., Natural antioxidants from spices. 1992, in: Phenolic Compounds in Foods and Their Effect on Health II, Antioxidants and Cancer Prevention (eds. M-T. Huang, C-T. Ho, C.Y.H. Lee). ACS Symposium Series No. 507. ACS Press, Washington DC, pp. 72-86.

85. Palitzsch A., Schulte H., Lotter D., Steichele A., Effect of natural spices, spice extracts, essential oils, extraction residues, and synthetic antioxidants on the breakdown of pork fat and model lipids. III. Spice extracts, water vapor-volatile and nonvolatile extraction compounds and extraction residues. Flaischwirtschaft, 1974, 54, 63-68.

86. Palitzsch A., Schulte H., Metzl F., Baas H., Effect of natural spices, spice extracts, essential oils, extraction residues, and synthetic antioxidants on the decomposition of pork fat and model lipids. I. Effect on natural spices and spice extracts on pork fat. Flaischwirtschaft, 1969, 49, 1349-1354.

87. Park D., Xiong Y.L., Oxidative modification of amino acids in porcine myofibrillar protein isolates exposed to three oxidizing systems. Food Chem., 2007, 103, 607-616.

88. Platt A.A., Gieseg S.P., Inhibition of protein hydroperoxide formation by protein thiols. Redox Rep., 2003, 8, 81-86.

89. Pokorný J., Davídek J., Influence in interactions of proteins with oxidized lipids on nutrition and sensory value of food. Acta Alimentaria Polonica, 1979, 5, 87-95.

90. Pokorný J., Davídek J., Chocholatá V., Pánek J., Bulantová H., Janitz W., Valentová H., Vierecklová M., Interactions of oxidized ethyl linoleate with collagen. Nahrung - Food, 1990, 34, 159-169 .

91. Pokorný J., Kołakowska A., Lipid - protein and lipid - saccharide interactions. 2003, in: Chemical and Functional Properties of Food Lipids (eds. Z.E. Sikorski, A. Kołakowska). CRC Press LLC, Boca Raton, Florida, pp. 345-362.

92. Priyadarsini K.I., Maity D.K., Naik G.H., Kumar M.S., Unnikrishnan M.K., Satav J.G., Mohan H., Role of phenolic O-H and methylene hydrogen on the free radical reactions and antioxidant activity of curcumin. Free Radical Bio Med., 2003, 35, 475-484.
93. Pyrcz J., Hęś M., Kowalski R., Korczak, J., Einfluss ausgewählter Antioxidantien auf die Qualität von Rohwurst (Effect of antioxidants addition on the quality of Polish raw sausages). Fleischwirtschaft, 2007, 9, 115-118 (in German, English abstract).

94. Raksakantong P., Siriamornpun S., Ratseewo J., Meeso N., Optimized drying of Kaprow leaves for industrial production of holy basil spice powder. Dry Technol., 2011, 29, 8, 974-983.

95. Rice-Evans C., Burdon R., Free-radical-lipid interactions and their pathological consequences. Prog. Lipid Res., 1993, 32, 71-110.

96. Saeed S., Fawthrop S.A, Howell N.K., Electron spin resonance (ESR) study of free radical transfer in fish lipid-protein interaction. J. Sci. Food Agric., 1999, 79, 1809-1816.

97. Saito K., Jin D-H., Ogawa T., Muramoto K., Hatakeyama E., Yasuhara T., Nokihara K., Antioxidative properties of tripeptide libraries prepared by the combinatorial chemistry J. Agric. Food Chem., 2003, 51, 3668-3674.

98. Santé-Lhoutellier V., Engel E., Aubry L., Gatellier P., Effect of animal (lamb) diet and meat storage on myofibrillar protein oxidation and in vitro digestibility. Meat Sci., 2008, 79, 777-783.

99. Shahidi F., Zhong Y., Novel antioxidants in food quality preservation and health promotion. Eur. J. Lipid Sci. Tech., 2010, 112, SI, 930-940.

100. Sikorski Z.E., Białka-budowa i właściwości. 2002, in: Chemia żywności (ed. Z.E. Sikorski), WNT Warszawa, pp. 243-277 (in Polish).

101. Soladoye O.P., Juárez M.L., Aalhus J.L., Shand P., Estévez M., Protein oxidation in processed meat: Mechanisms and potential implications on human health. Compr. Rev. Food Sci. F., 2015, 14, 106-122.

102. Takacsová M., Pribela A., Faktorová M., Study of antioxidative effects of thyme, sage, juniper and oregano. Nahrung - Food, 1995, 39, 241-243.

103. U.S. National Library of Medicine. In Haz-Map: Occupational Exposure to Hazardous Agents, 2010, [http://hazmap.nlm.nih.gov].

104. Utrera M., Estévez M., Oxidation of myofibrillar proteins and impaired functionality: underlying mechanisms of the carbonylation pathway. J. Agric. Food Chem., 2012, 60, 8002-8011.

105. Utrera M., Rodríguez-Carpena J.G., Morcuende D., Estévez M., Formation of lysine-derived oxidation products and loss of tryptophan during processing of porcine patties with added avocado byproducts. J. Agric. Food Chem., 2012, 60, 3917-3926 .

106. Utrera M., Morcuende D., Estévez M., Fat content has a significant impact on protein oxidation occurred during frozen storage of beef patties. LWT - Food Sci. Technol., 2014a, 56, 62-86.

107. Utrera M., Morcuende D., Estévez M., Temperature of frozen storage affects the nature and consequences of protein oxidation in beef patties. Meat Sci., 2014b, 96, 1250-1257.

108. Vainio H., Weiderpass E., Fruit and vegetables in cancer prevention. Nutr. Cancer., 2006, 54, SI, 111-142.

109. Veberg A., Vogt G., Wold J.P., Fluorescence in aldehyde model systems related to lipid oxidation. LWT - Food Sci. Technol., 2006, 39, 562-570.

110. Vekiari S.A., Oreopoulou V., Tzia C., Thomopoulos C.D., Oregano flavonoids as lipid antioxidants. J. Am. Oil Chem. Soc., 1993, 70, 483-487.

111. Viljanen K., Kivikari R., Heinonen M., Protein-lipid interactions during liposome oxidation with added anthocyanin and other 
phenolic compounds. J. Agric. Food Chem., 2004, 52, 1104-1111 .

112. Viljanen K., Protein oxidation and protein-lipid interactions in different food models in the presence of berry phenolics (dissertation). 2005, University of Helsinki, Department of Applied Chemistry and Microbiology. $87+36 \mathrm{pp}$.

113. Villaverde A., Ventanas J., Estévez M., Nitrite promotes protein carbonylation and Strecker aldehyde formation in experimental fermented sausages: are both events connected? Meat Sci., 2014, 98, 665-672.

114. Waszkowiak K., Szymandera-Buszka K., Hęś M., Effect of ethanolic flax (Linum usitatissimum L.) extracts on lipid oxidation and changes in nutritive value of frozen-stored meat products. Acta Sci. Pol. Technol. Aliment., 2014, 13(2), 135-144.

115. Xiong Y.L., Protein oxidation and implications for muscle food quality. 2000, in: Antioxidant in Muscle Foods (eds. E. Decker, C. Faustman, J.L.B. Clemente). Chichester, UK: Wiley, pp. 85-111.

116. Xiong H., He X., Ding C, Zhang Y., Kumar V., Holbrook S.R., Identification of functional modules in protein complexes via hyperclique pattern discovery. Pac. Symp. Biocomput, 2005, 10, 221-232.

117. Xiong Y.L., Blanchard S.P., Ooizumi T., Ma Y., Hydroxyl radical and ferryl-generating systems promote gel network formation of myofibrillar protein. J. Food Sci., 2010, 75, C215-221.

118. Zamora R., Alaiz M., Hidalgo F.J., Feed-back inhibition of oxidative stress by oxidized lipid/amino acid reaction products. Biochemistry, 1997, 36, 15765-15771.

119. Zhang W., Xiao S., Ahn D.U., Protein oxidation: basic principles and implication for meat quality. Crit. Rev. Food Sci., 2013, 53, 1191-1201.

120. Zhang Y., Smuts J.P., Dodbiba E., Rangarajan R., Lang J.C., Armstrong D.W., Degradation study of carnosic acid, carnosol, rosmarinic acid, and rosemary extract (Rosmarinus officinalis L.) assessed using HPLC. J. Agric. Food Chem., 2012, 60, SI, 9305-9314.

Submitted: 30 September 2015. Revised: 16 March 2016. Accepted: 13 May 2016. Published on-line: 5 October 2016. 
